\title{
Resolution of Possible Paradoxical Responses of Gonadotropins to Thyrotropin-Releasing Hormone with Bromocriptine Therapy in a Patient with Follicle-Stimulating Hormone-Secreting Pituitary Adenoma
}

\author{
LEILANi B MERCADO-ASIS, KEIGo YASUDA, \\ Masayoshi ISHIZAWA, Tatsuo ISHIZUKA, Masanori MURAYAMA, \\ KUNIYASU SHIMOKAWA* AND KIYOSHI MIURA \\ The Third Department of Internal Medicine and *Department of \\ Laboratory Medicine, Gifu University School of Medicine, Gifu \\ 500, Japan
}

\begin{abstract}
We report the effectiveness of bromocriptine therapy in resolving the abnormal responses of plasma FSH and LH to TRH in a 70-year-old male with FSH-secreting pituitary macroadenoma who had unsuccessful transsphenoidal pituitary surgery. In the pre-treatment and post-operative periods, respectively, basal plasma levels of FSH were increased to 88.7 and $65.6 \mathrm{mIU} / \mathrm{m} l$ (normal range; 8.5-32.4) but those of plasma $\mathrm{LH}$ were normal being 7.0 and $4.1 \mathrm{mIU} / \mathrm{ml}$; (normal range; 4.1 to 14.0). The responses of plasma FSH and LH to LHRH were exaggerated and their paradoxical responses to TRH were highly suggested. During the bromocriptine therapy, the basal level of plasma FSH was normalized and that of plasma LH remained normal. The magnitude of FSH and LH responses to LHRH decreased and their paradoxical responses to TRH were completely resolved.
\end{abstract}

Key words: Bromocriptine, FSH-oversecreting adenoma, Paradoxical response, Transsphenoidal pituitary surgery, Flushing.

(Endocrinol Japon 39: 401-406, 1992)

THE OCCURRENCE of paradoxical responses of plasma FSH and LH to TRH in gonadotroph adenomas is an established phenomenon both in vivo and in vitro [1-5]. Although the mechanism of this abnormal response has remained unclear, recent evidence favors more of a primary pituitary tumor involvement wherein TRH acts directly to release $\mathrm{FSH}$ and $\mathrm{LH}$ from $\mathrm{FSH}$-secreting adenoma [5]. Moreover, it has been demonstrated that an abnormal increase in the plasma level of FSH in response to TRH in a patient with FSH-secreting adenoma [2] disappeared after transsphenoidal removal of the pituitary tumor. The dopamine agonist bromocriptine has shown to have a direct

Received: December 11, 1991

Accepted: April 28, 1992

Correspondence to: Dr. Keigo YASUDA, The Third Department of Internal Medicine, Gifu University School of Medicine, 40 Tsukasa-machi, Gifu 500, Japan. inhibitory effect on excessive gonadotropin secretion in gonadotroph tumor cells in vivo $[4,5]$ and in vitro $[4,6]$. However, no case has yet been reported related to the effect of bromocriptine on the paradoxical response of gonadotropins to TRH in gonadotroph adenoma. We hereby report the effectiveness of bromocriptine in the resolution of highly suggested paradoxical response of FSH to TRH in a patient with FSH-secreting pituitary adenoma with normalization of plasma FSH secretion.

\section{Materials and Methods}

Case description

A 74-year-old male was referred to us with a pituitary tumor. In September, 1988 he began to 
experience progressive flushing. There was no accompanying headache, vomiting, nausea or visual disturbance. He was admitted to our institution in June 1990. Basal plasma FSH level had increased to $88.7 \mathrm{mIU} / \mathrm{m} l$ with a normal plasma $\mathrm{LH}$ value of $7.0 \mathrm{mIU} / \mathrm{ml}$ [7]. Other plasma hormone levels on admission are shown in Table 1. Magnetic resonance imaging of the brain showed a pituitary macroadenoma measuring 26.7 $\times 33.0 \times 30 \mathrm{~mm}$. He underwent pituitary transsphenoidal surgery in August, 1990 but even after the operation plasma FSH remained high (Fig. 1). The plasma $\alpha$-subunit measured at this time was also high at $5.9 \mathrm{ng} / \mathrm{ml}$ (normal value; less than 0.5 $\mathrm{ng} / \mathrm{ml}$ ). An immunocytochemical study showed the tumor to be positive for FSH, LH and ACTH but negative for TSH and GH. No staining for PRL and $\alpha$-subunit was done. Histologically, the tumor cells varied in size and shape, and were arranged in papillary or diffuse fashion with some follicle formations and some cells containing eosinophilic granular cytoplasm. A single-dose bromocriptine test (2.5 mg, Basle, Switzerland) showed slight suppression of plasma levels of FSH: basal: 105.3; nadir: $77.9 \mathrm{mIU} / \mathrm{ml}$; LH: basal: 8.7 ; nadir: 6.6 $\mathrm{mIU} / \mathrm{m} l$; and $\alpha$-subunit: basal: 7.6 ; nadir: 5.6 $\mathrm{ng} / \mathrm{ml}$.

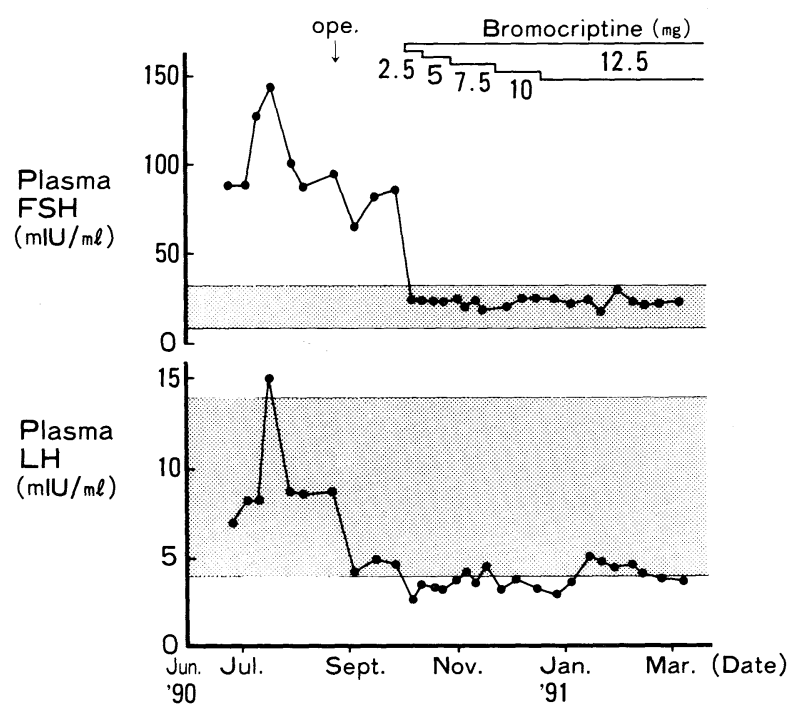

Fig. 1. Clinical course of the patient before and during bromocriptine therapy. Normal ranges (shaded areas): plasma FSH, 8.5-32.4 mIU/ml; plasma LH, 4.1-14.0 $\mathrm{mIU} / \mathrm{ml}$. ope, pituitary transsphenoidal surgery.

\section{Endocrine studies}

All baseline blood samples were withdrawn between 0800 and $0900 \mathrm{~h}$ after an overnight fast and at least $1 \mathrm{~h}$ of bed rest. Status of the pituitary-gonadal axis function before and during the treatment was assessed and monitored. Plasma samples were drawn at $0,15,30,60,90$ and 120 min after an iv bolus injection of LHRH (100 $\mu \mathrm{g}$, Tanabe Pharm. Co., Osaka), TRH (500 $\mu \mathrm{g}$, Tanabe Pharm. Co., Osaka), GRH (100 $\mu \mathrm{g}$, Sumitomo Pharm. Co., Tokyo) and CRH (100 $\mu \mathrm{g}$, Peptide Institute, Osaka). A placebo test was performed before operation and during the bromocriptine therapy: $1.0 \mathrm{ml}$ of saline was injected by iv bolus and responses of plasma FSH and LH were determined. Medical therapy was initiated after the patient agreed. Treatment with bromocriptine was given initially at a minimum tolerable dose of 2.5 to $5.0 \mathrm{mg} /$ day. The clinical course was monitored by determining plasma FSH and LH.

Plasma hormones were directly measured with commercially available kits: FSH, LH, TSH and PRL with SPAC-S Kits (Daiichi Radioisotope Co., Ltd., Tokyo), GH with a hGH RIA Kit (Dainabot Co., Ltd., Tokyo), ACTH with an IRMA kit (Mitsubishiyuka Co., Ltd., Tokyo), and plasma cortisol with a RIA kit (SPAC KIT DAIICHI, Daiichi Radioisotope Co., Ltd., Tokyo). Percent cross-reactivities for TSH of the anti-FSH and anti-LH serum used in the RIA kits were $2.63 \%$ and $2.3 \%$, respectively. Cross-reaction for FSH of the anti-LH serum used in the RIA kits was $2.38 \%$. Plasma $\alpha$-subunit was generously measured by Prof. Reiko Demura (Tokyo Women's Medical College). Plasma hormone normal ranges are shown in Table 1. An immunocytochemical study was done with a DAKO kit (DAKO Corp., California, USA). The antiserum to human LH crossreacted $0 \%$ for $\mathrm{TSH}$ and $12 \%$ for $\mathrm{FSH}$, and that to human FSH cross-reacted $10 \%$ for LH.

\section{Results}

Basal plasma FSH, LH and other hormone levels

With the initial bromocriptine dose of 2.5 $\mathrm{mg} /$ day, there was a prompt reduction in the plasma level of FSH (Fig. 1) and this was later maintained within the normal range. Plasma LH 
levels which were normal or remained slightly high prior to the treatment decreased to the low-normal range or were somewhat low during bromocriptine therapy. Table 1 shows the other plasma hormone levels during the course of the therapy. Basal plasma testosterone was low during the pretreatment period and was suppressed thereafter. During the bromocriptine administration, most of the plasma hormone levels were maintained within their respective normal ranges or values. A decrease in PRL and an increase in TSH were noted.

\section{Plasma FSH and LH responses to LHRH}

As shown in Fig. 2-A, exaggerated responses of plasma FSH and LH to LHRH [7] were noted during the pretreatment period in July, 1990. Even after the transsphenoidal pituitary surgery in September, 1990, such abnormal response of plasma FSH persisted and the plasma LH response was maintained in the low normal range. A post-operative LHRH test for plasma $\alpha$-subunit also showed the following response: basal: 7.1, peak: $11.2 \mathrm{ng} / \mathrm{ml}$. A repeat test in December, 1990, 3 months after the initiation of bromocriptine, showed normalization of FSH response to LHRH, with the plasma LH response remaining normal and unchanged. This was confirmed in February, 1991.

Responses of plasma FSH and LH to other stimuli before and during bromocriptine therapy

Fig. 2-B shows the paradoxical responses of plasma FSH and $\mathrm{LH}$ to TRH during the pretreat- ment period in July 1990 as follows: FSH: basal: 89.1, peak: $131.2 \mathrm{mIU} / l$; LH: basal: 8.2, peak: 11.3 $\mathrm{mIU} / \mathrm{l}$. A placebo test done in August, 1990 showed unequivocal negative results. Such abnormal responses were apparent even after transsphenoidal pituitary surgery when tested in September, 1990, 3 weeks after the pituitary operation. The values were as follows: FSH: basal: 84.8 , peak: $111.3 \mathrm{mIU} / l$; LH: basal: 4.9, peak: $11.0 \mathrm{mIU} / \mathrm{l}$. Alpha-subunit also responded to TRH as follows: basal: 5.9 , peak: $9.8 \mathrm{ng} / \mathrm{m} l$. In November, 1990, 2 months after the initiation of bromocriptine therapy, a repeat test showed negative responses of plasma FSH and LH which were confirmed on reexamination 2 months later. A placebo test done in February, 1991, the 5th month of drug treatment, again showed unequivocal negative results.

Plasma FSH and LH did not respond to other provocation tests such as GRH and CRH conducted during the pretreatment period (data not shown).

\section{Other endocrine test results}

During bromocriptine therapy, plasma ACTH and cortisol responses to $\mathrm{CRH}$ were normal, as follows: ACTH: basal: 14.0, peak: $40.0 \mathrm{pg} / \mathrm{ml}$; cortisol: basal: 7.7 , peak: $13.5 \mu \mathrm{g} / \mathrm{d} l$. Their responses remained intact when tested on the 5 th month of bromocriptine therapy as follows: ACTH: basal: 35.0, peak: $66.4 \mathrm{pg} / \mathrm{ml}$; cortisol: basal: 6.5 , peak: $11.2 \mu \mathrm{g} / \mathrm{d} l$. Plasma TSH responded normally to TRH during the pretreatment period as follows: basal: 5.6, peak: 17.7 $\mu \mathrm{U} / \mathrm{ml}$, and throughout the course of therapy: November, 1990: basal: 8.5, peak: $19.2 \mu \mathrm{U} / \mathrm{ml}$,

Table 1. Basal hormone levels during the pretreatment period, postoperative period and during bromocriptine therapy

\begin{tabular}{lcccc}
\hline Plasma hormone & Pretreatment & Postoperative & $\begin{array}{c}\text { During bromocriptine } \\
\text { therapy }\end{array}$ & $\begin{array}{c}\text { Normal } \\
\text { range/value }\end{array}$ \\
\hline $\mathrm{FSH}(\mathrm{mIU} / \mathrm{m} l)$ & 88.7 & 65.6 & $18.5-30.5$ & $8.5-32.4$ \\
$\mathrm{LH}(\mathrm{mIU} / \mathrm{m} l)$ & 7.0 & 4.1 & $2.6-5.6$ & $4.1-14.0$ \\
testosterone $(\mathrm{ng} / \mathrm{m} l)$ & 1.3 & 0.3 & $<0.2$ & $4.0-11.0$ \\
$\mathrm{TSH}(\mu \mathrm{U} / \mathrm{m} l)$ & 3.7 & 2.0 & $3.9-8.5$ & $0.4-4.4$ \\
$\mathrm{FT}_{3}(\mathrm{ng} / \mathrm{d} l)$ & 3.3 & 3.5 & $3.1-3.5$ & $2.6-5.9$ \\
$\mathrm{FT}_{4}(\mathrm{ng} / \mathrm{d} l)$ & 0.8 & 1.0 & $0.57-1.38$ & $0.8-2.0$ \\
$\mathrm{PRL}_{(\mathrm{ng} / \mathrm{m} l)}$ & 3.7 & 2.9 & $<1.0$ & $<15.0$ \\
$\mathrm{GH}(\mathrm{ng} / \mathrm{m} l)$ & 0.3 & 0.3 & $<0.3$ & $<0.5$ \\
$\mathrm{ACTH}(\mathrm{pg} / \mathrm{m} l)$ & 12.8 & 13.3 & $18.2-26.5$ & $7.6-30.0$ \\
cortisol $(\mu \mathrm{g} / \mathrm{d} l)$ & 10.9 & 7.1 & $6.6-10.3$ & $5.5-21.3$ \\
\hline
\end{tabular}




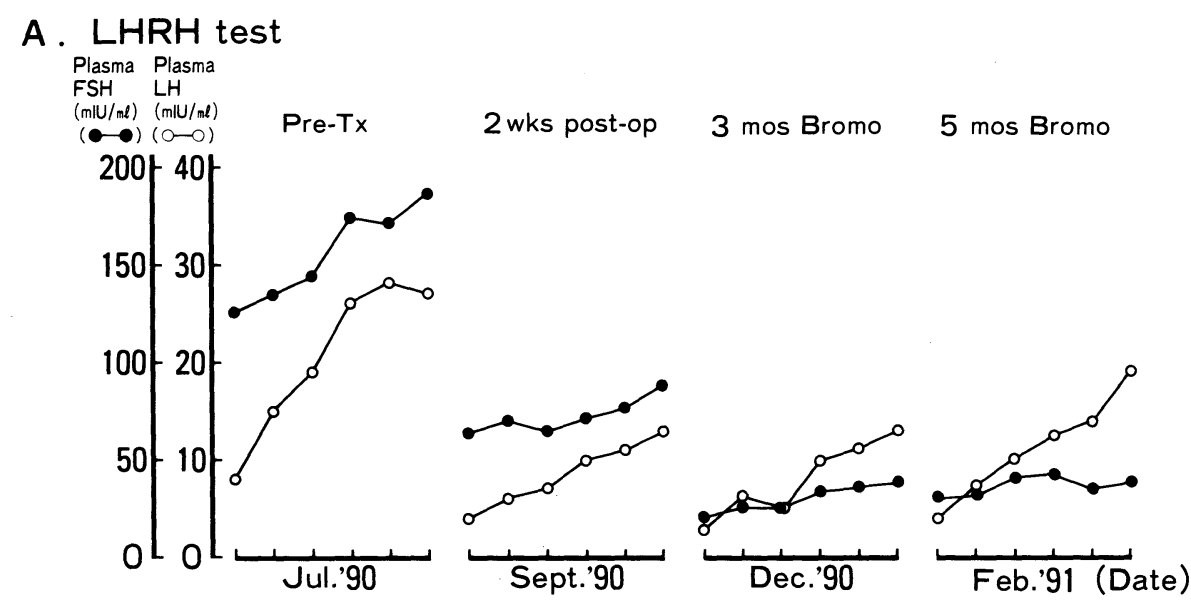

\section{B. TRH test} $\begin{array}{ll}\text { Plasma } & \text { Plasma } \\ \text { FSH } & \text { LH } \\ (\mathrm{ml} / \mathrm{m} / \mathrm{ml}) & (\mathrm{mlU} / \mathrm{ml}) \\ (\bullet-0) & (0-0)\end{array}$

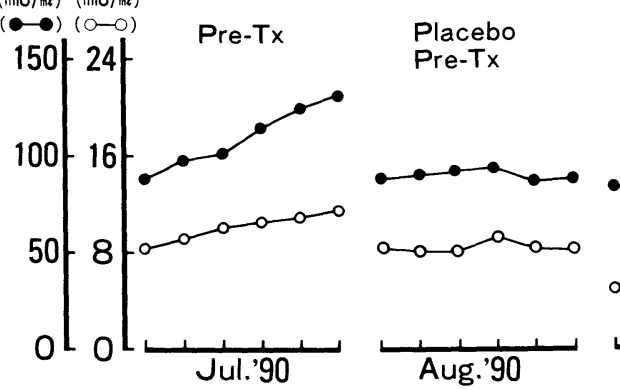

3 wks post-op

2 mos Bromo

4 mos Bromo

Placebo 5 mos Bromo

Fig. 2. Plasma FSH and LH responses to LHRH (100 $\mu \mathrm{g}$, iv bolus) and to TRH (500 $\mu \mathrm{g}$, iv bolus) before and during bromocriptine (Bromo) therapy. Pre-Tx, pretreatment; post-op, postoperative.

and January, 1991: basal: 4.5, peak: $16.4 \mu \mathrm{U} / \mathrm{m} l$. The response of plasma $\mathrm{GH}$ to $\mathrm{GRH}$ was low before the treatment, as follows: basal: less than 0.3 , peak: $0.5 \mathrm{ng} / \mathrm{m} l$, but was suppressed thereafter during the bromocriptine administration.

\section{Pituitary tumor size reduction during bromocriptine} therapy

Two months after the start of bromocriptine administration, repeat MRI showed a decrease in the size of the tumor from a postoperative diameter of $26.7 \times 20.0 \times 23.3 \mathrm{~mm}$ to $20.0 \times 16.0 \times$ $20.0 \mathrm{~mm}$.

\section{Discussion}

To our knowledge, the present report is the first in vivo study that showed the effectiveness of bromocriptine therapy in the resolution of highly suggested paradoxical responses of plasma FSH and $\mathrm{LH}$ to TRH in FSH-secreting pituitary adenoma. Snyder et al. [8] has shown that the responses of FSH and LH to TRH differ, the former is primarily that of an intact FSH, while that of the latter is primarily of an LH subunit. Uncombined alpha and LH-beta subunit has been shown to cross-react in the intact LH immunoassay [9]. Although the pretreatment plasma LH level was often normal or a little high in our patient, the positive immunocytochemical staining for LH and the presence of a paradoxical response of this hormone to TRH would indicate that the adenoma secreted not only FSH but also LH-beta. The cross-reaction of the $\mathrm{LH}$ assay kit used in the present study with FSH was $2.38 \%$. It is possible that the paradoxical response of $\mathrm{LH}$ to TRH reflects the cross-reactivity of LH with FSH. The mechanism of the paradoxical responses to stimuli of various pituitary hormone-secreting tumors has remained less understood. As has been previously suggested, although the hypothalamic influence could not be totally ruled out $[10,11]$, the 
abnormality most likely lies in the diseased pituitary itself. Earlier reports suggested the possibility of a receptor defect $[12,13]$ or alteration in the hypothalamo-pituitary pathways $[14,15]$. Such a contention has been supported by the fact that the paradoxical responses to TRH disappeared after surgery not only in ACTH-secreting [16] and $\mathrm{GH}$-secreting tumors [17] but also in $\mathrm{FSH}$ secreting adenomas [2].

It has been previously reported that the GnRHreceptor-effector response is generated primarily through a $\mathrm{Ca}^{2+}$ mediated system [18]. On the other hand, it has recently been demonstrated by Levy and his colleagues that LHRH and TRH actions are effected through the pituitary tumor cell receptors of prolactinoma, corticotroph and somatotroph adenomas resulting in an increase in the inositol phospholipid turnover and intracellular $\mathrm{Ca}^{2+}[19,20]$. Although no investigation has been done in gonadotroph adenoma, we suggest that the disappearance of the paradoxical responses of FSH and $\mathrm{LH}$ to TRH and the normalization of the plasma FSH secretion in our patient could possibly be attributed to the effect of bromocriptine on these signal transduction pathways.

Recently, it has become evident that some of clinically silent pituitary adenoma show immunohistochemically positive staining for one or more hormones, with normal levels of blood hormones [21]. This is apparent in our case where the tumor was positive not only for FSH and LH but also for ACTH, and the plasma levels of $\mathrm{LH}$ were often within the normal range and plasma ACTH was normal. Since the antiserum to LH cross-reacted $12 \%$ for $\mathrm{FSH}$, the staining for $\mathrm{LH}$ might be due to a cross-reaction. However, we did not have any data on the cross-reaction of the ACTH antiserum to $\mathrm{LH}$ which was used. Although the mechanism of such an occurrence is less clarified, it has been suggested that there is a failure of hormone release in vivo and the hormone is stored and lyzed in the cell or an abnormal hormone is produced and has no biological activity [21]. Since we measured only the immunoreactivity of the hormones and not their bioactivity, we could not further elucidate this.

Lastly, bromocriptine induced a reduction in the size of the tumor in our patient. This observation has long been demonstrated in other pituitary tumors most particularly in prolactinoma and acromegaly [22], and recently in normoprolactinemic Cushing's disease as well [23]. Further follow-up may be necessary to elucidate the mechanism of tumor size reduction by bromocriptine in FSH-secreting adenoma.

In summary, we have shown that bromocriptine was effective in the resolution of the paradoxical responses of gonadotropins to TRH and the normalization of FSH secretion in a patient who had FSH-secreting pituitary adenoma. The mechanism involved could have taken place at the receptor or post-receptor level.

\section{Acknowledgments}

We are grateful to Prof. Reiko Demura (Tokyo Women's Medical College) for the measurement of plasma $\alpha$-subunit.

This work was supported in part by a grant from the Ministry of Health and Welfare, Japan to assist research on "Disorders of the Adrenal Gland" and the "Hypothalamo-Pituitary Disorders".

\section{References}

1. Snyder PJ, Muzyka R, Johnson J, Utiger RD (1980) Thyrotropin-releasing hormone provokes abnormal follicle-stimulating hormone (FSH) and luteinizing hormone responses in men who have pituitary adenomas and FSH hypersecretion.J Clin Endocrinol Metab 51: 744-748.

2. Harris RI, Schatz NJ, Gennarelli T, Savino PJ, Cobbs WS, Snyder PJ (1983) Follicle-stimulating hormone-secreting pituitary adenomas: correlation of reduction of adenoma size with reduction of hormonal hypersecretion after transsphenoidal surgery. J Clin Endocrinol Metab 56: 1288-1293.

3. Berezin M, Olchovsky D, Pines A, Tadmor R, Lunenfeld B (1984) Reduction of folliclestimulating hormones (FSH) secretion in FSHproducing pituitary adenoma by bromocriptine. $J$ Clin Endocrinol Metab 59: 1220-1223.

4. Kwekkeboom DJ, de Jong FH, Lamberts SWJ (1989) Gonadotropin release by clinically nonfunctioning and gonadotroph pituitary adenomas in vivo and in vitro: relation to sex and effects of thyrotropin-releasing hormone, gonadotropin- 
releasing hormone, and bromocriptine. J Clin Endocrinol 68: 1128-1135.

5. Vance ML, Ridgway EC, Thorner MO (1985) Follicle-stimulating hormone- and $\alpha$-subunitsecreting pituitary tumor treated with bromocriptine. J Clin Endocrinol Metab 61: 580-584.

6. Kwekkeboom DJ, Hofland LJ, van Koetsveld PM, Singh R, Van de Verge JH, Lamberts SWJ (1990) Bromocriptine increasingly suppresses the in vitro gonadotropin and $\alpha$-subunit release from pituitary adenomas during long term culture. J Clin Endocrinol Metab 71: 718-724.

7. Aono T, Matsumoto S, Kumamoto E, Sasaki Y, Tamada T, Mizuno M, Iizuka R, Shizume K, Demura H, Hibi I, Irie M, Shishiba Y, Tomoda Y, Mori T, Imura H, Nakano S, Moridono S, Oota Z, Kahara M, Mori H (1988) Multi-center clinical studies on immunoradiometric assays (SPAC-S LH, SPAC-S FSH) for measurement of serum LH and FSH using pituitary gonadotropin standards. Clin Endocrinol (Tokyo) 36: 1087-1097.

8. Snyder PJ (1987) Gonadotroph cell pituitary adenomas. Endocrinol Metab Clin 16: 279-289.

9. Snyder PJ, Bashey HM, Kim SU, Chappel SC (1984) Secretion of uncombined subunits of luteinizing hormone by gonadotroph cell adenomas. J Clin Endocrinol Metab 59: 1169-1175.

10. Matsukura S, Kakita T, Hirata Y, Yoshimi H, Fukase M, Iwasaki Y, Kato Y, Imura H (1979) Effects of bromocriptine on pituitary tumour size. Br Med J 2: 700-703.

11. Oki S, Nakao K, Tanaka I, Horii K, Nakai Y, Shimbo S, Watanabe M, Nakane T, Kuwayama A, Kageyama N, Imura H (1981) Concomitant secretion of adrenocorticotropin, $\beta$-endorphin and $\gamma$ melanotropin from perfused pituitary tumor cells of Cushing's disease: effects of lysine vasopressin, rat median eminence extracts, thyrotropinreleasing hormone, and luteinizing hormonereleasing hormone. J Clin Endocrinol Metab 52: $42-49$.

12. Pieters GFF, Smals AGH, Benraad TJ, Kloppenborg PWC (1979) Plasma cortisol response to thyrotropin-releasing hormone and luteinizing hormone-releasing hormone in Cushing's disease. J Clin Endocrinol Metab 48: 874-876.

13. Peck V, Gershengorn C (1980) Differential regulation of thyrotropin releasing hormone receptors in neoplastic rodent mammotropic, adrenocorticotropic and thyrotropic pituitary cells in culture. J Clin Endocrinol Metab 50: 1144-1146.

14. Krieger DT, Cordon EM (1978) Cyproheptadine treatment of Nelson's syndrome: restoration of plasma ACTH circadian periodicity and reversal of response to TRH. J Clin Endocrinol Metab 46: 349-352.

15. Pieters GFF, Smals AGH, Goverde HJM, Meyer PE, Kloppenborg PWC (1982) Adrenocorticotropin and cortisol responsiveness to thyrotropinreleasing hormone and luteinizing hormonereleasing hormone discloses two subsets of patients with Cushing's disease. J Clin Endocrinol Metab 55: 1188-1197.

16. Pieters GFFM, Hermus ARMM, Meijer E, Smals AGH, Kloppenborg PWC (1989) Predictive factors for initial cure and relapse rate after pituitary surgery for Cushing's disease. J Clin Endocrinol Metab 69: 1122-1126.

17. Hoyte KM, Martin JB (1975) Recovery from paradoxical growth hormone responses in acromegaly after transsphenoidal selective adenomectomy. J Clin Endocrinol Metab 41: 656-659.

18. Conn PM, Mates MD, Rogers DC, Seay SG, Smith WA (1984) GnRH-receptor-effector-response coupling in the pituitary gonadotrope: $\mathrm{a} \mathrm{Ca}^{2+}$ mediated system. In: Fotherby K, Pal SB (eds) The Role of Drugs and Electrolytes in Hormonogenesis. Water de Gruyter \& Co., Berlin, 85-103.

19. Levy A, Lightman SL (1989) Effects of thyrotropin-releasing hormone and gonadotropinreleasing hormone on inositol phospholipid turnover and endocrinologically inactive pituitary adenomas and prolactinomas. J Clin Endocrinol Metab 69: 122-126.

20. Levy A, Lightman SL, Hoyland J, Mason WT (1990) Inositol phospholipid turnover and intracellular $\mathrm{Ca}^{2+}$ responses to thyrotropin-releasing hormone, gonadotropin-releasing hormone and arginine vasopressin in pituitary corticotroph and somatotroph adenomas. Clin Endocrinol 33: 73-79.

21. Kovacs K, Horvath E (1988) Pathology of pituitary adenomas. In: Collu R, Brown GM, Van Loon GR (eds) Clinical Neuroendocrinology. Blackwell Scientific Publications, Boston, vol. 1: 333-351.

22. Wass JAH, Williams J, Charlesworth M, Kingsley DPE, Halliday AM, Doniach I, Rees LH, McDonald I, Besser GM (1982) Bromocriptine in management of large pituitary tumours. Br Med J 284: 1908-1911.

23. Hayashi H, Mercado-Asis LB, Murayama M, Yamakita N, Yasuda K, Miura K (1990) Reduction of pituitary tumor size with clinical and biochemical improvement with bromocriptine in a normoprolactinemic Cushing's disease. Endocrinol Japon 37: 875-882. 